UDC $541.64+543.226$

\title{
STUDY OF THE MUTUAL EFFECT OF PHOSPHORUS-CONTAINING FERTILIZERS AND CLAY MINERALS OF ALUMINOSILICATE TYPE ON THE PRODUCTIVITY OF AGRICULTURAL PRODUCTS AND THE ECOLOGICAL CONDITION OF BROWN- BROWN SOILS
}

\author{
Z.R.Agayeva ${ }^{1}$, B.G.Mammadova ${ }^{2}$, Sh.A.Naseri ${ }^{1,3}$, E.E.Jabbarov ${ }^{1}$, S.G.Mammadova ${ }^{1}$, \\ Ch.M.Shabanova ${ }^{1}$, Kh.L.Rafiyeva ${ }^{4}$, E.M.Aliyev ${ }^{1}$ \\ ${ }^{1}$ M.Nagiyev Institute of Catalysis and Inorganic Chemistry, NAS of Azerbaijan \\ ${ }^{2}$ Institute of Soil Science and Agrochemistry, NAS of Azerbaijan \\ ${ }^{3}$ Iran, Anzali, Guilan, Technical University \\ ${ }^{4}$ Baku State University \\ agayeva-zenfira@mail.ru \\ shab.nasseri@yandex.ru
}

Received 26.06.2020

Accepted 14.01.2021

\begin{abstract}
The input of phosphorus-containing type clay minerals into the fertile soil, on the background of mineral fertilizers of the aluminum-silicate type, significantly improves the water-physical and agrochemical characteristics of the soil and improves its ecological condition. The both presence of clay minerals and mineral fertilizers in the soil creates the prerequisites for improving soil fertility due to the effect on mobile phosphorus.
\end{abstract}

Keywords: brown-brown soil, agricultural products, corn, clay materials, mobile phosphorus.

doi

\section{Introduction}

Recently, the soil of the Absheron peninsula of the Republic of Azerbaijan has been exposed to a number of undesirable factors. In Absherone there is 20-25 thousand hectares of oil-contaminated soil, which pollution degree ranges from 1.2 to $50 \%$ or more. A number of authors conducted work on the study of changes in the composition and properties of the soil exposed to oil and oil products [1-2]. It has been established that at entering to soil oil and oil products deep and often irreversible changes in the physical, morphological, physicochemical, and microbiological properties of soils occur. Bituminous substances significantly degrades the properties of the soil as a nutrient substrate for plants, and due to the hydrophobicity of the oil, the flow of moisture to the roots of plants is difficult, which leads to physiological changes [3]. During the transformation process petroleum hydrocarbons are able to form toxic compounds, which have carcinogenic properties and resistance to microbiological degradation, so that able to transfer into plants
[4-5]. All this affects the quality of agricultural products cultivated on such soil and poses a significant threat to human life [6]. Harmful soil pollutants can pass into water (for example, alkali metals, which are contained in the soil in the form of highly soluble compounds), into plants and, therefore, into animals and human. Although emissions of these toxic elements to the soil are relatively small, but their constant effect, to some extent, creates a source of sustainable pollution. So, the influence of oil is followed by soil degradation, which is determined by the combined action of the physicochemical, enzymatic, and microbiological transformation of oil components and oil products on it [7]. Numerous studies conducted in various natural zones over the world have shown that crude oil entering the soil has a significant and long-term effect on all soil processes. At penetrating to a depth of $1 \mathrm{~m}$ or more in sandy soil and $0.5-0.6 \mathrm{~m}$ in loams, it saturates them in a volume of $1-15 / \mathrm{m}$. As a result, the soil remains infertile for 10-15 years or more [8]. At pre- 
sent, in areas of oil production, soil, vegetation and wildlife are being degraded, agricultural efficiency is declining, in particular, the productivity of cotton and other crops has been sharply decreased, the productivity of pastures has been decreased almost 2 times, and the collection of medicinal herbs has been decreased. Currently, the problem of ecological assessment of cotton soils is not fully understandable, although this production is widely developed in some lowlying regions of the republic. This assessment should be based on a comprehensive study of soil and environmental factors in order to increase cotton productivity by eliminating undesirable factors [9]. Studies of the processes of sorption and desorption, as well as biodegradation of hydrocarbons in soils, regarding the relationship of these processes, revealed that the presence of free iron and aluminum in them are potential indicators of the reactivity of the mineral phase [10]. These components can affect the structure and properties of organic compounds in the composition of soils. The term aging includes all ongoing processes that are interconnected and time-dependent, taking into account a rather long period of accumulation of pollutants, processes of constant anthropogenic impact, a long time and extent of rehabilitation of natural objects. After a certain period of time, organic compounds become less sensitive to the effects of natural factors and show resistance to degradation [11]. Over time, the soil loses its self-cleaning properties, bacteria and fungi become saturated and lose the ability to consume organic pollutants as an energy source. In order to renew the soil composition it should be applied the mineral fertilizers and pesticides that again poison the soil. To date, various mechanical, physicochemical, and biological methods of purification are used to clean oil-contaminated soils [12-13]. However, none of the methods listed above makes it possible to achieve total restoration of complete soil properties.

Given the above, the search and development of optimal methods for cleaning the environmental objects from highly toxic hydrocarbons and improving the biological activity of the soil is one of the urgent tasks up today. It should be noted that in our republic a lot of at- tention is paid to this problem, however, the issues of optimizing the physical conditions of soil fertility, restoring the optimal waterresistant and wind-resistant soil structure still remain incomplete. Processing of the contaminated soil with natural adsorbents, zeolites does not allow to obtain the desired final results [14]. In recent years, scientific and practical interest is given to chemically interaction of new generation interpolymer complexes as an effective structurants of soils and ground [15]. Such reagents are capable in the shortest time, within a few hours from the time of application, to increase the amount of water-resistant $(>0.25$ $\mathrm{mm})$ and water-stable (1> $\mathrm{mm})$ aggregates in the soil to the optimum parameters (more than $50 \%$ ), that leads to improved soil fertility. However, this method is somewhat unprofitable, as the desorption of reagents of this type is somewhat difficult. That is why it was advisable to select an alternative method of improving soil from environmental objects by selecting environmentally friendly natural material [16]. Studies in this direction have established that the input of bentonite clay into the soil on the background of mineral fertilizers improves the yield of agricultural products, while enhancing the physicochemical and agrochemical properties of the soil [17].

\section{Results and discussions}

The purpose of the work is to improve the ecological condition of the soil for corn sowing. The intended goal was achieved by applying bentonite clay to the soil, along with a small amount of phosphorus-containing mineral fertilizers. Earlier [18], based on the studies conducted on brown-brown soil in the presence of bentonite clay (Absheron peninsula) in it, it was found that adding clay to the soil effectively affects the productivity of eggplant crops. In the presented work, by the example of planting corn crops, it was possible to visually trace the dynamics of productivity growth and give a corresponding assessment of the influence of the combined effect of bentonite clay and phosphorus fertilizer on soil fertility. Research was carried out on a pilot plot $\left(100 \mathrm{~m}^{2}\right)$ of the Scientific-Research Institute of Agriculture and Veg- 
etable Growth. For sowing purpose it was used "Zagatala-68" sort of the corn seeds.

The studies were carried out according to the following scheme:

1) the control background, i.e. soil not treated with bentonite clay. ers $\mathrm{P}_{2} \mathrm{O}_{5}$

2) background with phosphorus fertiliz-

3) background with bentonite clay at the rate of $10 \mathrm{t} / \mathrm{g}$

4) bentonite clay at the rate of $10 \mathrm{t} / \mathrm{g}$

Table 1 shows the results of the experiments.

By analyzing the data obtained, it is possible to establish that, compared with the control variant, the growth dynamics of corn crops on the soil with bentonite clay plus fertilizer is quite clearly traced. So, in the control variant, the growth of corn was $140 \mathrm{~cm}$, then with the joint application of clay and fertilizer the growth was already $240 \mathrm{~cm}$, i.e. almost doubled.

Figure shows the experimental plot for sowing corn, the size between rows of sowing was $75 \mathrm{~cm}$, and between plants $-25 \mathrm{~cm}$.

Table 2 shows the results of ingestion of fertilizer by soil when bentonite clay is added to it.

From the tabular data it can be established that the amount of $\mathrm{P}_{2} \mathrm{O}_{5}$ in the control version was $22.22 \mathrm{mq} / \mathrm{kq}$, and in the background version $-67.36 \mathrm{mq} / \mathrm{kq}$. It can be established that the input of bentonite clay has a positive effect on soil absorption of fertilizers $27.78 \mathrm{mq} / \mathrm{kq}$.

Table 1. Study of the effect of bentonite clay and mineral fertilizer on the growth of corn $(\mathrm{cm})$

\begin{tabular}{|l|l|l|l|l|l|}
\hline Experiment Design & $05 / 18$ & $05 / 27$ & $06 / 07$ & $06 / 20$ & $07 / 05$ \\
\hline Control background & 25 & 50.6 & 83.2 & 90.5 & 140 \\
\hline Background $+\mathrm{P}_{2} \mathrm{O}_{5}(80)+$ & 35 & 80.9 & 143 & 175 & 200 \\
\hline Background $+\mathrm{P}_{2} \mathrm{O}_{5}(80)+10$ t/g bentonite clay & 48 & 90.1 & 152 & 225 & 240 \\
\hline 10 t/g bentonite clay & 46 & 90.5 & 149 & 176 & 220 \\
\hline
\end{tabular}

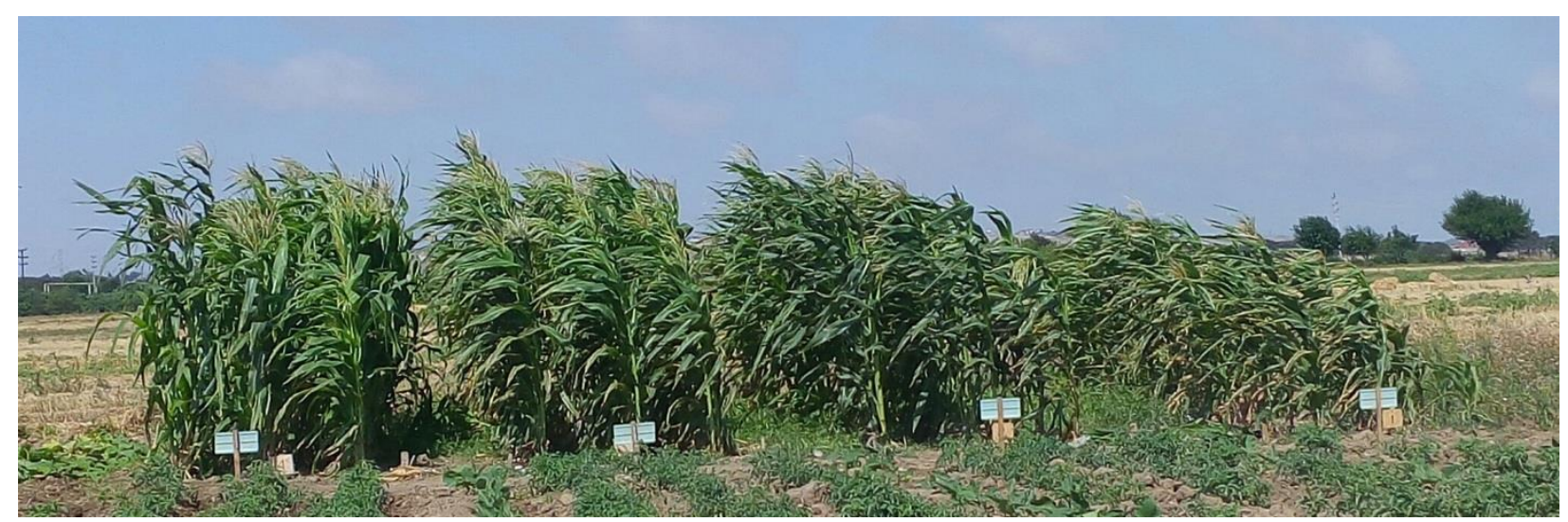

Experimental plot for sowing corn.

Table 2. Corn yields indicators

\begin{tabular}{|c|l|c|c|c|c|}
\hline \multirow{2}{*}{$\mathrm{N}$} & \multicolumn{2}{|c|}{ Experiment Design } & \multicolumn{3}{c|}{ Corn crops } \\
\cline { 3 - 6 } & & $\mathrm{P}_{2} \mathrm{O}_{5} \mathrm{mg} / \mathrm{kg}$ & $\mathrm{K}_{2} \mathrm{O} \mathrm{mg} / \mathrm{kg}$ & $\mathrm{pH}$ & Electrical conductivity, dm/m \\
\hline 1 & Control background & 22.22 & 78.32 & 8.74 & 0.22 \\
\hline 2 & Background $\mathrm{P}_{2} \mathrm{O}_{5}(80)$ & 67.36 & 72.30 & 8.55 & 0.26 \\
\hline 3 & Background $\mathrm{P}_{2} \mathrm{O}_{5}(80)+10$ t/g bentonite clay & 27.78 & 60.25 & 8.53 & 0.26 \\
\hline 4 & 10 t/g bentonite clay & 23.33 & 78.32 & 8.40 & 0.25 \\
\hline
\end{tabular}

Table 3. The biological productivity of corn

\begin{tabular}{|l|l|c|c|c|}
\hline $\mathrm{N}$ & \multicolumn{1}{|c|}{ Experiment Design } & $\begin{array}{c}\text { The number of plants } \\
\text { per } 1 \mathrm{~m}^{2}\end{array}$ & $\begin{array}{c}\text { Weight of corn, } \\
\mathrm{kg}\end{array}$ & $\begin{array}{c}\text { The number of plants } \\
\text { per } 1 \mathrm{ha}, \mathrm{kg} / \mathrm{ha}\end{array}$ \\
\hline 1 & Control option & 5.3 & 0.24 & 24 \\
\hline 2 & Background $\mathrm{P}_{2} \mathrm{O}_{5}(80)$ & 5.3 & 0.53 & 53 \\
\hline 3 & Background $\mathrm{P}_{2} \mathrm{O}_{5}(80)+10$ t/g bentonite clay & 5.3 & 0.82 & 82 \\
\hline 4 & 10 t/g bentonite clay & 5.3 & 0.61 & 61 \\
\hline
\end{tabular}


These results indicate an increase its yield. The determination of biological productivity was carried out by calculating the productivity of plants per $1 \mathrm{~m}^{2}$. Plant productivity per $1 \mathrm{~m}^{2}$ is $0.75 \times 0.25=0.19 \mathrm{~m}^{2}$, in one hectare 10000 $\mathrm{m}^{2} / 0.19 \mathrm{~m}^{2}=52631$ plants, $1 \mathrm{~m}^{2}-52631 / 10000$ $\mathrm{m}^{2}=5.3$ plants. The results of studies of crop productivity are shown in Table 3.

It was found that if the productivity of corn in the control version was $24 \mathrm{c} / \mathrm{ha}$, then in the case of the combined application of bentonite clay and fertilizers to the soil, this value increased to $82 \mathrm{c} / \mathrm{ha}$.

\section{Main conclusions}

Based on the conducted studies, it was concluded that the combined input of bentonite clay and phosphate fertilizers into the soil has a versatile effect on soil fertility, improves the physical and chemical properties of the soil, enhances the biological activity of the soil and positively affects the vegetation processes of agricultural products and their productivity, that is the main advantage at conducting soil improvement measures [19]. It was established that the effect of the both presence of bentonite clay and phosphorus-containing fertilizers in the soil is caused by the synergistic action of colloidal properties in the crystalline structure of aluminosilicate rocks, first with phosphorus-containing fertilizer, and then with weak bonds of the soil itself. Presumably, the mechanism of action consists in the fact that the silicic acid anion displaces the phosphate anion from insoluble phosphates, moreover, it is also likely that the silicate ion, as a complexing agent, forms a silicate-phosphorus complex of the type $\mathrm{O}-\mathrm{Si}-\mathrm{O}-\mathrm{P}-\mathrm{O}$, which passes better through root pores and improves soil absorption of mobile phosphorus [20]. Moreover, the chemical interaction of silicic acid with phosphates improves the phosphorus state of fertile soils by changing the adsorption properties of the soil [21]. At irrigating soils, the removal of free phosphorus from their root layer and the pollution of natural waters by them and by impurities in phosphorus fertilizer is one of the urgent problems. Our studies contribute to solving this important problem by reducing the removal of free phosphorus from the upper soil horizons. The studies carried out in this direction are of great economic importance.

\section{References}

1. Jusifrade $X$. Interest to Azerbaijan fields intensifies. J.Caspian Energy. 2007. No 45. P. 82-85.

2. Monakhov S.K., Monakhova G.A. O sovremennom sostoyanii ekosistemy Kaspiyskogo morya. Problemy monitoringa ekosistem Kaspiyskogo morya. Materialy mezhdunar. nauch. konf. Makhachkala. IPTS DGU. 2002. S. 16-17.

3. Gurbanov E.M. Okhrana rastitel'nosti resursov Atropatana. Akademik Həsən Oliyevin 100-illik yubileyinə həsr olunmuş "Ekologiya: təbiət və cəmiyyət problemləri" Beynalxalq konfransı. Bak1. 2007. S. 334.

4. Tulikov A.M., Sutyagin V.P. Nekotoryye aspekty otsenki energeticheskikh potokov $\mathrm{v}$ agroekosistemakh. Vestnik RASKHN. 2004. № 4. S. 62-65.

5. Abdullayev S.M. Modeli ekologicheskoy ochistki i upravleniye prirodopol'zovaniyem. Vestnik Chelyabinskogo gos. un-ta. Ser. Ekologiya. Prirodopol'zovaniye. 2007. № 6. S. 7-20

6. Dobrovol'skiy G.V. Nikitin Ye.D., Funktsii pochv v biosfere i ekosistemakh (Ekologicheskoye dvizheniye pochv.) M.: Nauka, 1990. 240 s.

7. Spravochnik inzhenera-ekologa neftedobyvayushchey promyshlennosti po metodam analiza okruzhayushchey sredy. M.: Nedra, 1999. № 2.634 s.

8. Bokrus D.O. Khimiya okruzhayushchey sredy. M.: Khimiya, 1982. $350 \mathrm{~s}$.

9. Mamedova N.KH. Rol' ustoychivykh k boleznyam sortov khlopchatnika. Akademik Həsən Oliyevin 100 illik yubileyinə həsr olunmuş "Ekoloqiya: təbiət və cəmiyyət problemləri" Beynalxalq konfrans1. Bak1. 2007. S. 224.

10. Mikhon'ko E.P. Migratsiya zagryaznennykh veshchestv v pochvakh i sopredel'nykh sredakh. L.: Gidrometeoizdat, 1985. 136 s.

11. Garmashov V.M. Obrabotka pochvy v landshaftnykh sistemakh zemledeliya. Puti sokhraneniya plodorodiya pochvy i povysheniya produktivnosti sel'skokhozyaystvennykh kul'tur v adaptivno-landshaftnom zemledelii Tsentral'nogo Chernozem'ya: materialy zasedaniya Territorial'nogo koordinatsionnogo soveta "Problemy zemledeliya TSCHZ" Voronezh: Istoki. 2009. CH. 1 S. 25-29.

12. Filonov A.E., Karpov A.V., Puntus I.F., Akimenko V.K., Boronin A.M. Microbial degradation of phenantlirene and naphthalene in soil model systems. INTAS Symposium. M.: 1997. P. 30.

13. Zhitin YU.I., Prokopova L.V. Effektivnost' ispol'zovaniya silitsitovykh bentonitov $\mathrm{v}$ kachestve prolongatorov azotnykh udobreniy. Materialy mezhdunarodnoy nauchno-prakticheskoy konfe- 
rentsii "Ekologicheskiye aspekty intensifikatsii sel'skokhozyaystvennogo proizvodstva" Penza. RIO PGSKHA. 2002. T. II. S. 248.

14. Nuriyev S.SH., Ishkayev T.KH. Mestnyye bentonity kak sredstvo polucheniya ekologicheski chistoy produktsii rasteniyevodstva. Kazan': AN RT. Izd-vo KGU. 1965. $156 \mathrm{s.}$

15. Kasymova ZH.S., Orazzhanova L.K., Klivenko A,N., Musabayeva B.KH. Aserzhanova D.K. Polucheniye i svoystva interpolimernykh kompleksov, sposobnykh k strukturoobrazovaniyu pochv. Prikladnaya khimiya. 2019. T. 92. Vyp. 2. C. 177-186.

16. Məmmədova B.H., Mehdiyev H.C. Muğan düzü suvarılan boz-çəmən torpaqlarında mütəhərrik fosforun miqdarına serpentinitin 3 illik sonrakı təsiri Az. MEA Biologiya elmləri bölgəsi TAİ XI X cild. Bakı. Elm. 2011. S. 91-95.

17. Agayeva Z.R., Mammadova B.G., Kazimova E.M., Talibli I.A., Efendiyeva S.G., Shabanova
Ch.M. Influence alyumosilicate clays on ecological condition of Apsheron lands. Azerb. chem. Jour. 2020. № 1. P. 82-86.

18. Mehdiyev H.C. Naxçıvan muxtar respublikası dă torpaqlarının mineroloji tərkibi və onun kənd təsərrüfatında əhəmiyyəti. Bakı. Elm. 2018. 134 s.

19. Məmmədova B.H. Şirvan düzü suvarılan boz-çəmən torpaqlarının su-fiziki və kimyəvi xassələrinin yaxşılaşdırılmasında yüksək maqneziumlu serpentinitin rolu. "Aqrar elmi" J. 1-2- ci buraxılış. 1997. S. 99-102.

20. Dedov A.V., Lukin L.Yu., Kosilova A.N. Effektivnost' ispol'zovaniya udobreniy pri vozdelyvanii ozimoy pshenitsy. Plodorodiye. 2002. № 1. S. 27-28.

21. Matychenkov I.V. Vzaimnoye vliyaniye kremniya, fosfornykh azotnykh udobreniy $\mathrm{v}$ sisteme pochva-rasteniye. Disser.... kand. biologich. nauk. M.: MGU im. Lomonosova. 2002. 136 s.

\section{FOSFOR TəRKIBBLI GÜBRӘLəRIN VӘ ALUMOSILIKAT TIPLII GILLORIN BOZ-QONUR TORPAQLARDA KəND TəSӘRRÜFATI BITKILIVRININ MəHSULDARLIĞINA Və TORPAĞIN EKOLOJI VӘZIYYəTINə BİRGə TəSIRIININ TəDQIQİ}

\section{Z.R.Ağayeva, B.H.Məmmədova, Ç.M.Şabanova, E.E.Cabbarov, S.G.Məmmədova, Ş.A.Naseri, X.L.Rəfiyeva, E.M.Oliyev}

Torpağın ekoloji mühitini sağlamlaşdırmaq, torpağa verilən mineral gübrələrin səmərəliliyini artırmaq üçün mineral gübrə fonunda torpağa verilən bentonit gilinin superfosfatla birlikdə istifadəsi torpağın su-fiziki, aqrokimyəvi xüsusiyyətlərinə və ekoloji mühitin sağlamlaşmasına əlverişli şərait yaradır ki, bu da bitkilərin məhsuldarlığına və torpaqda mütəhhərrik fosforun miqdarına müsbət təsir göstərir.

Açar sözlor: Becərilon boz-qonur torpaq, qarğıldalı bitkisi, mineral gillar, bitkinin fosforla təminatı.

\section{ИЗУЧЕНИЕ ВЗАИМНОГО ДЕЙСТВИЯ ФОСФОРСОДЕРЖАЩИХ УДОБРЕНИЙ И ГЛИНИСТЫХ МИНЕРАЛОВ АЛЮМОСИЛИКАТНОГО ТИПА НА ПРОДУКТИВНОСТЬ СЕЛЬСКОХОЗЯЙСТВЕННОЙ ПРОДУКЦИИ И ЭКОЛОГИЧЕСКОЕ СОСТОЯНИЕ БУРО-КОРИЧНЕВЫХ ПОЧВ}

\section{З.Р.Агаева, Б.Г.Мамедова, Ч.М.Шабанова, Э.Э.Джабаров, С.Г.Мамедова, Ш.А.Насери, Х.Л.Рафиева, Э.М.Алиев}

Введение в плодородную почву, на фоне минеральных удобрений фосфорсодержащего типа, глинистых минералов алюмосиликатного типа способствует значительному улучшению водно-физической и агрохимической характеристики почвы и оздоровления его экологического состояния Совместное присутствие в почве глинистых минералов и минеральных удобрений создает предпосылки для улучшения плодородности почвы за счет влияния на подвижный фосфор,

Ключевые слова: буро-коричневая почва, сельскохозяйственная продукция кукуруза, глинистье материаль, подвижный фосфор. 